\title{
Music as an intervention in health projects*
}

\author{
A música como intervenção em projetos de saúde \\ La música como intervención en proyectos de salud
}

How to cite this article:

Donda DC, Leão ER. Music as an intervention in health projects. Rev Esc Enferm USP. 2021;55:e03715. doi: https://doi.org/10.1590/S1980-220X2020002203715

\section{Darlene Cristina Donda ${ }^{1}$ \\ Eliseth Ribeiro Leão ${ }^{2}$}

* Extracted from the dissertation: "A música como intervenção de cuidado em projetos de saúde”, Mestrado Profissional em Enfermagem, Faculdade Israelita de Ciências da Saúde Albert Einstein, 2017.

1 Centro Universitário Adventista de São Paulo, São Paulo, SP, Brazil.

2 Instituto Israelita de Ensino e Pesquisa Albert Einstein, Hospital Israelita Albert Einstein, São Paulo, SP, Brazil.
Corresponding author:

Darlene Cristina Donda

Rua Rodolfo Belz, 220, Apto

184-B, Lar São Paulo

CEP 05639-010 - São Paulo, SP, Brazil

dondaenf@yahoo.com.br

\begin{abstract}
Objective: To identify and characterize music projects in the health area, their therapeutic goals, theoretical frameworks, evaluation/monitoring, and dissemination of their results for a possible structure model for this process. Method: Descriptive study with multiple cases and documental analysis. Results: Nine projects have participated in this study; these were predominantly in São Paulo and conducted with the adult population in public institutions. The coordinators were mostly women, specialists, with a qualification in health, music, or both. The interventions were performed live, with a mean of 60 minutes per week and repertoires selected by patients. Less than half indicated basing their activities in some theoretical framework or any type of project monitoring. Therapeutic goals related to social insertion and restoring self-esteem, citizenship, protagonism, and communication were pointed out. Conclusion: The theoretical indication of the music projects was scarce. Around half the analyzed projects indicated some type of evaluation and dissemination of the performed activities. Two projects only had some risk surveillance and scientific production out of their results, which has not enabled proposing a monitoring model for these initiatives.
\end{abstract}

DESCRIPTORS

Music; Music Therapy; Complementary Therapies; Mental Health; Nursing. 


\section{INTRODUCTION}

In Brazil, the history of health care has been through and still is undergoing constant changes. Since the last decades of the twentieth century, with the emergence of the Sanitary Reform and the implementation and consolidation of the Brazilian Unified Health System (SUS), it was necessary to rethink this model and adopt new healthcare practices, with an emphasis on integrality and equity, valuing social factors, subjectivity, and care. Human beings thus become the center of attention, determining which actions are required to achieve new goals: elaborate health products, provide care, broaden the understanding and appropriation of the health-disease process, and improve the users' quality of life, respecting and considering their singularities, beliefs, culture, and environment ${ }^{(1)}$.

In such context, new integrative and complementary care and treatment practices must be offered to health users in different clinical contexts; music is one of these practices. Music, the language of emotions, is both culture and art. It reproduces our internal feelings, the mixture of sensations, and can be found in all cultures. This is an accessible and lowcost therapeutic tool, with potential therapeutic and clinical use, for treating diverse clinical conditions and promoting quality of life $\mathrm{e}^{(2-3)}$.

Music has been employed in treating depression ${ }^{(4)}$, stress $^{(5)}$, schizophrenia ${ }^{(6)}$, and autism ${ }^{(7)}$. Studies show that music has an analgesic and anxiolytic property during surgeries $^{(8-9)}$ and has been used in intensive care units ${ }^{(10)}$, as well as in diagnostic procedures (endoscopy, colonoscopy) $)^{(11)}$.

Researchers investigating the experiences and attitudes of nurses regarding the use of music in an Intensive Care Unit (ICU) have shown its relevance to clinical practice and that, when included in the ICU environment, it can help nurses and relatives during mourning ${ }^{(12)}$. Researchers have shown that singing is an alternative and low-cost means of health maintenance for the elderly ${ }^{(13)}$. Music has been pointed as a health intervention from birth ${ }^{(14)}$ to death ${ }^{(15)}$, showing a potential for use in all the human life cycle.

Music is present in people's lives not only informally, but also in research projects worldwide which investigate its therapeutic potential for human health. This resource integrates also diverse actions and projects which are conducted by professionals with different academic qualifications.

A participation in the music group with patients of a Psychosocial Support Center (Centro de Apoio Psicossocial CAPS), during which many reflections have emerged, has encouraged and prompted the conduction of this study. The music group was formed by patients, most of whom were male, young people between 20 and 45 years old, with severe mental disorders, such as schizophrenia, mood disorders, and personality disorders, some with negative symptoms, such as blunted affect, hallucinations, and delirium, and others with more autonomy. During participation in this group, with the onset of a crisis in one of the patients, listening to reports from other participants, and reflections on the approach adopted in the group's management (and even the risks involved in this activity), it became clear that care practice is not always critical-reflexive, not always the proposed goals are evaluated based on criteria and, particularly, results and the possible risks involved are not always systematically evaluated. This has led to the necessity of this study. Such situation is even more worrying when interventions with a therapeutic potential are executed by professionals who have no basic or complementary qualification in the health area, especially when targeted at vulnerable populations, such as psychiatric patients.

Diverse activities involving music are known and even music projects related to health, such as the project Harmonia Enlouquece (literally, "Harmony Goes Crazy", a band of psychiatric patients in the Psychiatric Center of Rio de Janeiro) and the Saracura group (which develops actions in São Paulo hospitals), among others, which aim to favor well-being, emotional equilibrium, and humanized care in disease situations. However, the literature is limited regarding details and execution of these activities in clinical practice. There is apparently not much clarity (despite the good intentions) regarding the theoretical frameworks that support them, a rigorous analysis in relation to its appropriateness to each clinical context, and data from result monitoring to ensure the adoption of the best scientific evidence. This makes it difficult to analyze models, replicate them (each project becomes an end by itself) and its incorporation into a higher number of health institutions, despite the benefits pointed by diverse studies on the theme.

The number of projects using music on health and their characteristics is unknown in Brazil. In addition to the use of music, could there be similarities among the diverse existing projects? In what ways have these projects been evaluating and providing evidence for their clinical results? Which theoretical models may help in the implementation of music interventions in general and specialized health services? These are the questions that guide this study, whose results may narrow down the discussion on music as an intervention in contexts of healthcare, as well as identifying fundamental elements that facilitate the introduction and broadening of musical practices in a safe and effective way in the health area.

This study had the objectives of identifying and characterizing the music interventions of projects conducted in the health area in general (hospitals) and specialized settings (CAPS, Palliative Care, and others); identifying the therapeutic goals and the theoretical frameworks of projects characterized by music interventions in the health area; understanding the ways of evaluating, monitoring, and disseminating the results obtained by these projects; verifying whether the experiences found subsidize the proposal of a structural and monitoring model of projects that use music as an instrument of care in the health area.

\section{METHOD}

\section{Design OF STUDY}

Descriptive-exploratory study with a qualitative approach conducted through multiple case study and documental analysis. The potential of the multiple case study methodology is in the possibility of using multiple sources of data collection through literature review, interviews, questionnaires, and documental research ${ }^{(16-17)}$. 


\section{SAMPLE}

To identify music projects and their coordinators, the following procedures were adopted: 1) bibliographic research on PUBMED covering 20 years (1995 to 2015), using the descriptors: music; nursing; singing; health promotion; music therapy; mental health related to music; 2) search for projects on the internet with Google search and the Facebook social network, both directed at music and health.

To identify the projects, a search was also performed on Plataforma Lattes; however, this strategy showed no efficacy, as the curriculums had no information on names and data of the projects in which professionals might be participating.

The identified Brazilian music projects in the health area amounted to 37 . Out of these, two projects were observed to have been discontinued. Coordinators have been identified for only 11 projects. Out of 11 questionnaires to be accessed and answered by the music project coordinators in health institutions, two projects were excluded from the sample, given that these data were incomplete, which might compromise the analysis; therefore, nine projects were left to constitute this study's convenience sample.

\section{Data COLLECTION}

To meet the proposed goals, a questionnaire was elaborated and applied to the project coordinators via the SurveyMonkey platform, to facilitate submission, participation, and reception of information.

The conceptual model, which provided a basis for this questionnaire, was based on the literature regarding the guidelines for music intervention reports ${ }^{(18)}$ and the management of action projects ${ }^{(19)}$. The questionnaire was composed of the participant's characterization data, project coordinators, data of characterization of the music intervention and the project's theoretical framework, and data on evaluation, monitoring, and dissemination of the results obtained by the project.

The email with the link for access to the research questionnaire was sent to all 37 institutions responsible for these projects. When answers were not obtained from an expressive share of the institutions, other measures were taken with the purpose of obtaining information of contact data from project coordinators and broadening the possibilities for data collection. Such measures were contact by telephone with all the identified institutions and the identification of and contact with the coordinators, which resulted in 24 projects to which an email was forwarded at least twice with a link for questionnaire access.

The participants were also asked to forward documents related to the music projects, such as reports, scientific papers, and material on the project disseminated in the media.

\section{DATA TREATMENT AND ANALYSIS}

The content of the description of each case was elaborated through the answers of the project coordinators to the questionnaire and the data of secondary sources provided by them, in addition to those found on digital media, which were analyzed for information that complemented the answers to the questionnaires.
In this article, the projects are identified with fictional names of popular Brazilian songs randomly chosen by the researchers to guarantee the project's anonymity, as well as their data and information.

The numerical data were organized through descriptive statistical analysis and presented in graphics and tables. Qualitative analysis followed the methodology proposed for case study analysis ${ }^{(20)}$, in which each case was described through individual reports and a final matrix of case-crossover.

\section{ETHICAL ASPECTS}

This research was ethically approved in opinion number 1.369.165/2015 and participant consent was duly obtained in an Informed Consent Form.

\section{RESULTS}

Chart 1 presents the identification of the music projects participating in this study.

Chart 1 - Identification of music projects per fictional name, geographic location, and type of health institution where they are developed - São Paulo, SP, Brazil, 2016.

\begin{tabular}{|c|c|c|}
\hline PROJECTS & GEOGRAPHICAL LOCATION & INSTITUTION \\
\hline $\begin{array}{l}\text { Aquarela do } \\
\text { Brasil }\end{array}$ & São Paulo - SP & CAPS \\
\hline Brasileirinho & São Paulo - SP & CAPS \\
\hline $\begin{array}{l}\text { Chega de } \\
\text { saudade }\end{array}$ & São Paulo - SP & General hospital \\
\hline $\begin{array}{l}\text { Cabecinha no } \\
\text { ombro }\end{array}$ & Belém - PA & $\begin{array}{l}\text { University } \\
\text { hospital }\end{array}$ \\
\hline Mas que nada & São Paulo - SP & CAPS \\
\hline Roda vida & São Paulo - SP & CAPS \\
\hline $\begin{array}{l}\text { Um violeiro } \\
\text { toca }\end{array}$ & Três Lagoas - MS & General hospital \\
\hline $\begin{array}{l}\text { Garota de } \\
\text { Ipanema }\end{array}$ & Rio de Janeiro - RJ & $\begin{array}{l}\text { Psychiatric } \\
\text { hospital }\end{array}$ \\
\hline $\begin{array}{l}\text { Tocando em } \\
\text { frente }\end{array}$ & $\begin{array}{c}\text { Brazil (São Paulo, Sorocaba, } \\
\text { Marília), France, Portugal, Spain, } \\
\text { and Germany. }\end{array}$ & $\begin{array}{l}\text { Hospital and } \\
\text { elderly homes }\end{array}$ \\
\hline
\end{tabular}

A concentration of projects participating in this study was observed in Southeastern Brazil, especially in São Paulo city, conducted predominantly in public hospital institutions, CAPS and specialized psychiatry and elderly units. One of the projects includes countries other than Brazil, with specialized training for musicians to perform in hospitals ${ }^{(21)}$.

The profile of the musical group coordinators in the health area was composed mostly of women, aged 30 to 60 , specialists, with complete high education, related the health or music areas; there were also professionals with a background in both areas. Four coordinators reported performing the activities for remuneration.

With the answers provided in Chart 2, rationales are observed to have their main sources on personal interests and qualifications, and few have presented as a rationale, a priori, a therapeutic perspective. 
Chart 2 - Rationale of coordinators for idealization or participation in the music groups - São Paulo, SP, Brazil, 2016.

\begin{tabular}{|l|l|}
\hline PROJECTS & RATIONALE OF THE COORDINATORS \\
\hline $\begin{array}{l}\text { Aquarela do } \\
\text { Brasil }\end{array}$ & $\begin{array}{l}\text { "In addition to being a psychiatrist and } \\
\text { "I would like to work in this area, applying my } \\
\text { knowledge and providing to users the contact with } \\
\text { the musical language, contributing to their social } \\
\text { insertion" }\end{array}$ \\
\hline Brasileirinho & $\begin{array}{l}\text { "My personal study of percussion" } \\
\text { "The need for improving the musical quality of } \\
\text { the samba group, which happened from time to } \\
\text { service users" }\end{array}$ \\
\hline $\begin{array}{l}\text { Chega de } \\
\text { saudade }\end{array}$ & $\begin{array}{l}\text { "Believing that music may bring a positive } \\
\text { message and thus transform suffering into joy" }\end{array}$ \\
\hline $\begin{array}{l}\text { Cabecinha no } \\
\text { ombro }\end{array}$ & "Invitation to sing in the university hospital" \\
\hline Mas que nada & $\begin{array}{l}\text { "Perceiving how much patients enjoy and adhere } \\
\text { to projects involving music" }\end{array}$ \\
\hline Roda vida & $\begin{array}{l}\text { "Enjoying music and having played in a samba } \\
\text { school's drums section" }\end{array}$ \\
\hline Ipanema & $\begin{array}{l}\text { "Collaboration" } \\
\text { "Bringing joy to the hospitalized people" } \\
\text { interest in understanding the repercussion of music } \\
\text { in fighting stigma, interest in investigating the dyad } \\
\text { mental health and music" }\end{array}$ \\
\hline "Interest in registering the activities"
\end{tabular}

Most projects had the adult population as the focus of action. Regarding the time of existence of the projects, out of nine studied music projects, three had started a long time ago: Garota de Ipanema, 20 years; Aquarela do Brasil, 11 years; and $U m$ violeiro Toca, 10 years. The other studied projects had existed for less than five years.
The frequency of weekly activities was the most observed one, and one of the projects happens only upon invitation, with no specific frequency. Regarding the duration of each musical session, a mean duration of 60 minutes was prevalent.

Regarding personnel composition and education, three groups were composed only by the coordinator musicians. The other six groups had a varied composition, two or three types of professional with different qualifications, involving social assistant, psychologist, undergraduate student, nurse, physician, and musicians.

Concerning the existence of a physical and financial plan for the project, only two studied music groups reported having it.

Concerning musical repertoire selection, the criteria, the form of presentation, and instruments, the musical repertoire was mostly selected by patients, i.e., participants of music projects themselves. All the studied projects had live performances and the main musical instruments were percussion and acoustic guitar. One group diverged by using instruments made of recycled material.

Regarding privacy and the acoustic isolation of where these took place, all reported having no infrastructure with acoustic isolation and privacy.

Regarding the adoption of a theoretical framework for conducting the music project in the health environment and the existence of therapeutic goals or lack thereof, five music projects reported having no theoretical references as a basis for their interventions. However, seven indicated therapeutic goals.

Seven music projects reported having published no scientific articles or promoting itself on digital media, as well as no type of monitoring of activities and evaluation of risks related to music intervention.

A synthesis of the main characteristics of music projects is presented in Chart 3.

Chart 3 - Main characteristics of the music projects (final matrix of case-crossover) - São Paulo, SP, Brazil, 2016.

\begin{tabular}{|c|c|c|c|c|c|c|c|c|}
\hline \multicolumn{9}{|c|}{ MAIN CHARACTERISTICS OF THE MUSIC PROJECTS } \\
\hline $\begin{array}{l}\text { MUSIC } \\
\text { PROJECTS }\end{array}$ & FORMATION & PRESENTATION & $\begin{array}{l}\text { CHOICE OF } \\
\text { REPERTOIRE }\end{array}$ & $\begin{array}{l}\text { THEORETICAL } \\
\text { REFERENCE }\end{array}$ & $\begin{array}{l}\text { THERAPEUTIC } \\
\text { GOAL }\end{array}$ & MONITORING & MEDIA & $\begin{array}{c}\text { SCIENTIFIC } \\
\text { ARTICLE }\end{array}$ \\
\hline $\begin{array}{l}\text { Aquarela do } \\
\text { Brasil }\end{array}$ & $\begin{array}{l}\text { Physician and } \\
\text { musician }\end{array}$ & Live & Patients & Unspecified & $\begin{array}{c}\text { Social insertion } \\
\text { Citizenship } \\
\text { Psychosocial } \\
\text { care }\end{array}$ & Unspecified & $\begin{array}{l}\text { YouTube } \\
\text { Solidarity } \\
\text { economy } \\
\text { website }\end{array}$ & No \\
\hline Brasileirinho & Physician & Live & Patients & $\begin{array}{l}\text { Psychodrama } \\
\text { theater of the } \\
\text { oppressed, } \\
\text { Jungian } \\
\text { psychology }\end{array}$ & $\begin{array}{l}\text { Protagonism } \\
\text { Social } \\
\text { reintegration } \\
\text { Damage } \\
\text { reduction }\end{array}$ & $\begin{array}{c}\text { Evaluation of } \\
\text { risks of cravings } \\
\text { and relapsing } \\
\text { into alcohol and } \\
\text { drugs }\end{array}$ & No & No \\
\hline $\begin{array}{l}\text { Chega de } \\
\text { saudade }\end{array}$ & Nurse & Live & Patients & Unspecified & $\begin{array}{c}\text { Problem-solving } \\
\text { and increasing } \\
\text { well-being }\end{array}$ & Unspecified & No & No \\
\hline $\begin{array}{l}\text { Cabecinha no } \\
\text { ombro }\end{array}$ & Musician & Live & Coordinator & Unspecified & Unspecified & Unspecified & $\begin{array}{l}\text { YouTube } \\
\text { Website }\end{array}$ & No \\
\hline $\begin{array}{l}\text { Mas que } \\
\text { nada }\end{array}$ & $\begin{array}{l}\text { Psychologist } \\
\text { and musician }\end{array}$ & Live & Patients & $\begin{array}{c}\text { Reduction of } \\
\text { damage and } \\
\text { music }\end{array}$ & $\begin{array}{c}\text { Socialization } \\
\text { Improving self- } \\
\text { esteem, } \\
\text { Group } \\
\text { interaction } \\
\text { Stimulate } \\
\text { creativity }\end{array}$ & Unspecified & No & No \\
\hline
\end{tabular}




\begin{tabular}{|c|c|c|c|c|c|c|c|c|}
\hline \multicolumn{9}{|c|}{ MAIN CHARACTERISTICS OF THE MUSIC PROJECTS } \\
\hline $\begin{array}{l}\text { MUSIC } \\
\text { PROJECTS }\end{array}$ & FORMATION & PRESENTATION & $\begin{array}{l}\text { CHOICE OF } \\
\text { REPERTOIRE }\end{array}$ & $\begin{array}{c}\text { THEORETICAL } \\
\text { REFERENCE }\end{array}$ & $\begin{array}{l}\text { THERAPEUTIC } \\
\text { GOAL }\end{array}$ & MONITORING & MEDIA & $\begin{array}{l}\text { SCIENTIFIC } \\
\text { ARTICLE }\end{array}$ \\
\hline Roda vida & Psychologist & Live & $\begin{array}{l}\text { Coordinator } \\
\text { and Patients }\end{array}$ & Unspecified & $\begin{array}{c}\text { Develop } \\
\text { perception of } \\
\text { others } \\
\text { Increase in body } \\
\text { and musical } \\
\text { notions }\end{array}$ & Unspecified & No & No \\
\hline $\begin{array}{l}\text { Um violeiro } \\
\text { toca }\end{array}$ & Musician & Live & Coordinator & Unspecified & Unspecified & Unspecified & $\begin{array}{l}\text { YouTube } \\
\text { Facebook } \\
\text { Websites }\end{array}$ & No \\
\hline $\begin{array}{l}\text { Garota de } \\
\text { Ipanema }\end{array}$ & $\begin{array}{l}\text { Psychologist } \\
\text { and musician }\end{array}$ & Live & Patients & $\begin{array}{c}\text { Music therapy } \\
\text { Psychology } \\
\text { and Music } \\
\text { education }\end{array}$ & $\begin{array}{l}\text { Improve in } \\
\text { communication } \\
\text { Interaction } \\
\text { Self-esteem } \\
\text { Adherence to } \\
\text { treatment }\end{array}$ & Unspecified & No & No \\
\hline $\begin{array}{l}\text { Tocando em } \\
\text { frente }\end{array}$ & $\begin{array}{c}\text { Social } \\
\text { communication }\end{array}$ & Live & Coordinator & Reflection & Well-being & $\begin{array}{c}\text { Supervision } \\
\text { by health and } \\
\text { music personnel }\end{array}$ & $\begin{array}{c}\text { YouTube } \\
\text { Websites } \\
\text { Printed } \\
\text { Newspaper } \\
\text { Book }\end{array}$ & Yes \\
\hline
\end{tabular}

Departing from the studied experiences, it was not possible to identify congruent aspects to elaborate a model of structure and monitoring of projects using music as an instrument of healthcare.

\section{DISCUSSION}

Out of the 37 projects identified through this study methodology, nine (24\%) were included and accepted to participate in the research. This percentage is in accordance with participation estimates in other studies, since questionnaires which are sent to interviewees electronically achieve a mean of $25 \%$ return ${ }^{(22)}$.

The profiles of coordinators of musical groups in the health area comprised mostly women, specialists, aged 30 to 60. Except for one project, coordination was conducted by health professionals and most coordinators had also a background in music. Those who reported no music background mentioned a desire for studying it, denoting how much health professionals seek in art forms of fighting daily stress and end up associating them to their professional activities.

With this background, the desire for producing some beneficial effect during the music intervention is explicit, characterized by an intention of bringing to work the experience of what music brings them, as well as to the patients of the unit, by putting them in contact with the language of music and, through it, strengthen protagonism and the fight against stigma and diverse situations which illness, as well as treatment and hospitalization, entails.

Music therapy, as a discipline, was mentioned by only one project coordinated by a nurse and as a theoretical reference adopted in a project coordinated by a psychologist/musician. However, since neither have a specific education on this subject, this word is believed to have been used randomly. There are diverse forms through which music can get to patients and diverse conceptions adopted by other health professionals who are not music therapists, which present a very similar essence, since they use as a means music and its elements. They diverge by the specific activities that each one develops and the theoretical bases that support them. The music therapy process is developed only by music therapists, i.e., in the music therapy setting, patient and music therapist create (and recreate) life situations, aiming at achieving changes from the patient's complaint itself ${ }^{(23)}$. This study's sample was composed of diverse professionals (none a music therapist) who employ music, often with therapeutic goals, getting closer, thus, to the most appropriate definition of music therapy to be adopted in this context, which is based on the field of knowledge and not on a specific professional category related to it, as presented by the multilingual structured vocabulary DeCS - Health Sciences Descriptors, as the "use of music as an adjunctive therapy in the treatment of neurological, mental, or behavioral disorders" (24).

One of the characteristics of the studied music projects is the live performance, whose repertoire is mostly chosen by patients. However, the involvement of professionals in choosing and analyzing these songs is unclear. The therapeutic goals mention the use of music and these gatherings to strengthen protagonism, as an exercise and recovery of the participants' citizenship to later promote their social reintegration; on the other hand, the lack of a reflection on the risks of such attitude is revealed. Music produces emotions ${ }^{(25)}$ and may bring wonderful sensations and memories of well-being, joy, and euphoria, but may also lead to not so pleasant sensations, evoking negative elements, some situation or memory which leads to sorrow, suffering, distress, or even feelings and emotions that cannot be explained. This reflection is required before establishing how, when and in which way it will be used, as well as, in case of any critical situation, which professional conduct will be adopted.

Projects conducted for a long time present therapeutic goals without expressing a theoretical framework. Theoretical frameworks are used for circumscribing not only scientific research, but also professional practice, whatever it may be. In daily life, judgement of any phenomenon by common 
sense is based on a myriad of theoretical frameworks, which are learned in the family, with friends, during college, by reading, etc.

How is it possible thus to use music with therapeutic goals, if there is no clear theoretical framework? With no theoretical framework, it is not possible to estimate expectations, their magnitude, limitations, or understand any human phenomenon stemming from the musical experience. This is using music based only on common-sense, which is not recommended and even dangerous when it comes to health.

It is no surprise that musicians do not indicate a health theoretical framework - other than music itself - and, in a way, is more coherent with the performance of their activity, focused, so it would seem, on entertainment. What circumscribes their practice is musical technique and knowledge, which are, however, not indicated as or claimed to be promoters of therapeutic effects by these professionals, who are not from the health area. Particularly worrisome are the projects including health professionals (physician, nurse, and psychologist) with no overt frameworks for their musical practice in the hospital, since they aim at therapeutic results. The frameworks do exist; however, out of these professionals, few reported using one while coordinating music activities. In medicine, the cerebral processing of music and its psychophysiological effects could be mentioned $^{(26)}$, along with the Theory of Music Therapy ${ }^{(27)}$, and others. In nursing, the adoption of the Environmental theory or the Theory of Unitary Human Beings, for instance, could guide the search for changes of environment or of individual energy patterns which imply also psychophysiological changes, considering the principle of resonance ${ }^{(28)}$.

Thus, the projects which report no theoretical frameworks are carried, in our understanding, very loosely, as in these the repertoire is not chosen by the professionals. The professionals do not understand what they produce and whether it meets the indicated therapeutic goals; such attitude seems to constitute more a "desire to help" than knowledge of "how" to do so in a more structured and effective manner. There is a noticeable good will, but also a lack of theoretical preparation to deal with the theme.

If the therapeutic goals are related to social reintegration, this may be compromised if the elements and concepts which help developing the musical activity to achieve this goal are not discussed. Professionals should also know how to properly manage when the results are not those expected, such as in the mentioned and experienced situation during professional mental health practice. The challenge lies in maintaining patients as protagonists in mental health, aligned to the professional expertise of what is occurring in all of the process, including musical knowledge, the same way that pharmacological knowledge is used in the treatments, given that this is a health intervention.

On the other hand, even in projects indicating theoretical frameworks, the relation between theory and therapeutic goals is unclear.

The project is likely to follow the theoretical line in which the coordinator is inserted; however, unfortunately, when the theoretical approach was questioned, the answers did not present the expected depth to show paths to be replicated.

The expectation, thus, of outlining such path, identifying the elements to elaborate a model for support of music projects in the health area, was frustrated, given that, even among projects presenting some theoretical framework, there was no congruence between them, suggesting that each professional category tends to abide by frameworks which are familiar to their academic career. Such statement means that music meets diverse theoretical possibilities, which makes the approaches of each professional category unique. The construction of a more universal model is yet necessary to make music practice more effective and safer in the diverse clinical contexts in which it is inserted and in which principles that base the practice are still obscure. In this aspect, other inconsistencies have been observed. If psychodrama circumscribes the music intervention in one of the projects, as mentioned, how can repertoire selection be made by patients? Music in psychodrama sessions includes group and/or individual warm-up techniques articulated to auxiliary psychodramatic techniques, with the objective of bringing forth therapeutic material in a subliminal state. Therapeutic management of music in psychotherapy sessions is considered delicate, since it is necessary to have a large musical repertoire in each session, in addition to the need of developing some, if not much, musical sensitivity regarding the group and the protagonist to use it appropriately, since the therapeutic goals on stage are always what leads to the choice of applying this clinical management option to the patient ${ }^{(29)}$.

Jungian theory was also mentioned as theoretical framework; in this, humanity is said to share the behavioral patterns in music, religious symbolism, and art, constituting universal and collective consciousness values. These universal and collective values are said to be in the unconscious ${ }^{(29)}$ and, thus, working with music may activate archetypes which require previous work and recognition, as well as the musical potential for its onset, so that the activity is safely developed.

It is also noteworthy that only one project was coordinated by a nurse, although music is present in the Nursing Intervention Classification (NIC) and its first use as a form of healthcare was reported by Florence Nightingale in the nineteenth centur ${ }^{(29)}$. In this sense, it comes as a surprise that the coordinator attempts to search for a theoretical framework in a different subject (music therapy), showing a lack of knowledge of the fact that this profession originated, partially, from the work of Florence and American nurses during the world wars, in addition to research developed by Brazilian nurses who have presented nursing theoretical frameworks to support this type of healthcare intervention ${ }^{(30)}$.

This study presents some limitations, such as the reduced number of evaluated projects, although this is appropriate for the proposed methodology (multiple case study), with no possibility of generalizing the presented discussion. This has not enabled obtaining a broader landscape of how music projects are conducted in Brazil in health institutions, since literature on these projects is particularly scarce. However, low adherence by the identified projects suggests a frailty 
which might have been detected by coordinators upon noticing that they did not have the information requested by the researchers. Presential interviews could have also deepened some of the studied aspects and, although these depend on financial resources and time, they should be considered in future studies.

On the other hand, these results point to important reflections on the clinical practice of health professionals who work or wish to work with this type of intervention. Professional qualification to perform in this area, regardless of professional area, is indispensable. This is also a warning to health institutions managers who authorize music projects for the patients, showing that, although this intervention has a health potential, it is not entirely devoid of risks, even when aimed at entertainment. These aspects must be considered for music as care to become increasingly recognized, valued, and incorporated into our space.

\section{CONCLUSION}

This study has analyzed seven music projects developed in public health institutions. The indication of theoretical frameworks to support music intervention in the clinical context is almost nonexistent, even though therapeutic goals have been broadly mentioned.

Around half the analyzed projects indicated some type of evaluation of the conducted activities and dissemination in some type of media; however, only two projects reported monitoring of risks and scientific publication of their results.

It was not possible to propose, from this study's findings, a model for structure and monitoring of projects which have music as healthcare intervention, due to the low adherence of the contacted projects, the heterogeneity of the evaluated projects, and the absence of elements which can support such proposal. The need for new studies to consolidate effective, critical-reflexive, and safe practice in our space, specially concerning mental health, is thus acknowledged.

\section{RESUMO}

Objetivo: Identificar e caracterizar projetos musicais na área de saúde, seus objetivos terapêuticos, referenciais teóricos, avaliação/ monitoramento e disseminação dos resultados para um possível modelo de estrutura para esse processo. Método: Estudo descritivo com casos múltiplos e análise documental. Resultados: Participaram do estudo nove projetos, predominantemente concentrados em São Paulo e realizados com população adulta em instituições públicas. Os coordenadores eram majoritariamente mulheres, especialistas e com formação em saúde, em música ou ambas. As intervenções foram realizadas ao vivo, com média/semana de 60 minutos e repertório selecionado pelos pacientes. Menos da metade indicou pautar suas atividades em algum referencial teórico, ou algum tipo de monitoramento do projeto. Objetivos terapêuticos relacionados à inserção social, resgate de autoestima, cidadania, protagonismo e comunicação foram apontados. Conclusão: A indicação teórica dos projetos musicais foi escassa. Cerca de metade dos projetos analisados indicou algum tipo de avaliação e divulgação das atividades realizadas. Dois projetos apenas possuíam algum monitoramento de riscos e produção científica de seus resultados, o que não permitiu propor um modelo de acompanhamento para essas iniciativas.

\section{DESCRITORES}

Música; Musicoterapia; Terapias Complementares; Saúde Mental; Enfermagem.

\section{RESUMEN}

Objetivo: Identificar y caracterizar proyectos de música en el área de la salud, sus objetivos terapéuticos, referencias teóricas, evaluación/ seguimiento y difusión de resultados para un posible modelo de estructura para este proceso. Método: Estudio descriptivo, de casos múltiples y análisis documental. Resultados: Participaron en el estudio nueve proyectos, concentrados mayoritariamente en São Paulo y realizados con población adulta en instituciones públicas. Los coordinadores eran en su mayoría mujeres, especialistas y con formación en salud, música o ambas. Las intervenciones se realizaron en vivo, con una media de 60 minutos por semana y repertorio elegido por los pacientes. Menos de la mitad indicó que sus actividades se basaban en alguna referencia teórica o tener algún tipo de seguimiento del proyecto. Se propusieron objetivos terapéuticos relacionados con la inserción social, la recuperación de la autoestima, la ciudadanía, el protagonismo y la comunicación. Conclusión: La indicación teórica de los proyectos musicales fue escasa. Cerca de la mitad de los proyectos analizados indicaban algún tipo de evaluación y divulgación de las actividades realizadas. Dos proyectos presentaban solamente algún tipo de seguimiento de los riesgos y la publicación científica de sus resultados, lo que no ha permitido proponer un modelo de acompañamiento para estas iniciativas.

\section{DESCRIPTORES}

Música; Musicoterapia; Terapias Complementarias; Salud Mental; Enfermería.

\section{REFERENCES}

1. Campos RTO, Ferrer AL, Gama CAP, Campos GWS, Trapé TL, Dantas DV. Avaliação da qualidade do acesso na atenção primária de uma grande cidade brasileira na perspectiva dos usuários. Saúde Debate. 2014;38(n.esp.):252-64. doi: http://dx.doi.org/10.5935/01031104.2014S019

2. Melo GAA, Rodrigues AB, Firmeza MA, Grangeiro ASM, Oliveira PP, Caetano JA. Intervenção musical sobre a ansiedade e parâmetros vitais de pacientes renais crônicos: ensaio clínico randomizado. Rev Latino Am Enfermagem. 2018;26:e2978. doi: http://dx.doi. org/10.1590/1518-8345.2123.2978

3. Trahan T, Durrant SJ, Müllensiefen D, Williamson VJ. The music that helps people sleep and the reasons they believe it works: a mixed methods analysis of online survey reports. PLoS One. 2018;13(11):e0206531. doi: https://doi.org/10.1371/journal.pone.0206531

4. Aalbers S, Fusar-Poli L, Freeman RE, Spreen M, Ket JCF, Vink AC, et al. Music therapy for depression. Cochrane Database Syst Rev. 2017;(11):CD004517. doi: http://dx.doi.org/10.1002/14651858.CD004517

5. Linnemann A, Wenzel M, Grammes J, Kubiak T, Nater UM. Music listening and stress in daily life-a matter of timing. Int J Behav Med. 2018;25(2):223-30. doi: https://doi.org/10.1007/s12529-017-9697-5 
6. Geretsegger M, Mössler KA, Bieleninik $九$, Chen XJ, Heldal TO, Gold C. Music therapy for people with schizophrenia and schizophrenialike disorders. Cochrane Database Syst Rev. 2017;(5):CD004025. doi: https://doi.org/10.1002/14651858.cd004025.pub4

7. LaGasse AB. Social outcomes in children with autism spectrum disorder: a review of music therapy outcomes. Patient Relat Outcome Meas. 2017;8:23-32. doi: https://doi.org/10.2147/prom.s106267

8. Kühlmann AYR, de Rooij A, Kroese LF, van Dijk M, Hunink MGM, Jeekel J. Meta-analysis evaluating music interventions for anxiety and pain in surgery. Br J Surg. 2018;105(7):773-83. doi: https://doi.org/10.1002/bjs.10853

9. Rice KL, Castex J, Redmond M, Burton J, Guo JW, Beck SL. Bundling Interventions to Enhance Pain Care Quality (BITE Pain) in medical surgical patients. Ochsner J. 2019;19(2):77-95. doi: https://doi.org/10.31486/toj.18.0164

10. Ames N, Shuford R, Yang L, Moriyama B, Frey M, Wilson F, et al. Music listening among postoperative patients in the intensive care unit: a randomized controlled trial with mixed-methods analysis. Integr Med Insights. 2017;12:1-13. doi: https://doi. org/10.1177/1178633717716455

11. Bashiri M, Akçalı D, Coşkun D, Cindoruk M, Dikmen A, Çifdalöz BU. Evaluation of pain and patient satisfaction by music therapy in patients with endoscopy/colonoscopy. Turk J Gastroenterol. 2018;29(5):574-9. doi: https://doi.org/10.5152/tjg.2018.18200

12. Holm MS, Falun N, Gjengedal E, Norekval TM. Music during after-death care: a focus group study. Nurs Crit Care.2012;17(6):302-8. doi: https://doi.org/10.1111/j.1478-5153.2012.00525.x

13. Skingley A, Clift SM, Coulton SP, Rodriguez J. The effectiveness and cost-effectiveness of a participative community singing programme as a health promotion initiative for older people: protocol for a randomised controlled trial. BMC Public Health. 2011;11:142. doi: https:// doi.org/10.1186/1471-2458-11-142

14. Tabarro CS, Campos LB, Galli NO, Novo NF, Pereira VM. Effect of the music in labor and newborn. Rev Esc Enferm USP. 2010;44(2):44552. doi: http://dx.doi.org/10.1590/S0080-62342010000200029

15. Silva V, Sales C. Musical meetings as a resource in oncologic palliative care for users of a support home. Rev Esc Enferm USP. 2013;47(3):626-33. doi: http://dx.doi.org/10.1590/S0080-623420130000300015

16. Silva LA, Mercês NN. Estudo de casos múltiplos aplicado na pesquisa de enfermagem: relato de experiência. Rev Bras Enferm. 2018;71(3):1194-7. doi: http://dx.doi.org/10.1590/0034-7167-2017-0066

17. Triviños A. Introdução à pesquisa em ciências sociais: a pesquisa qualitativa em educação. São Paulo; Atlas; 2015. O positivismo; a fenomenologia; o marxismo.

18. Robb SL, Burns DS, Carpenter JS. Reporting guidelines for music-bases interventions. J Health Psychol. 2011; 16(2):342-52. doi: https:// doi.org/10.1177\%2F1359105310374781

19. Carvalho MCB. Avaliação de projetos sociais. In: Ávila CM. Avaliação de projetos sociais. $3^{a}$ ed. São Paulo: AAPCS; 2001. p. 59-90.

20. Yin RK. Estudos de casos: planejamento e métodos. $4^{\mathrm{a}}$ ed. Porto Alegre: Bookman; 2010.

21. Leão ER, Flusser V. Music for institutionalized elderly: perceptions of the intervening musicians. Rev Esc Enferm USP. 2008;42(1):7380. doi: https://doi.org/10.1590/S0080-62342008000100010

22. Manfreda K L, Bosnjak M, Berzelak J, Haas I, Vehovar V. Web surveys versus other survey modes: a meta-analysis comparing response rates. Int J Market Res. 2008;50(1):79-104. doi: https://doi.org/10.1177/147078530805000107

23. Leubner D, Hinterberger T. Reviewing the effectiveness of music interventions in treating depression. Front Psychol. 2017;8: 1109. doi: https://dx.doi.org/10.3389\%2Ffpsyg.2017.01109

24. Centro Latino-Americano e do Caribe de Informação em Ciências da Saúde (BIREME). Descritores em Ciências da Saúde (DeCS/MeSH) [Internet]. São Paulo: BIREME/OPAS/OMS; 2019 [citado 2019 set. 22]. Disponível em: http://decs.bvsalud.org

25. Casarotto FD, Vargas LS, Mello-Carpes PB. Música e seus efeitos sobre o cérebro: uma abordagem da neurociência junto a escolares. Rev Elo Diálogos Extensão. 2017; 6(2):55-60. doi: https://doi.org/10.21284/elo.v6i2.243

26. Chanda ML, Levitin DJ. The neurochemistry of music. Trends Cogn Sci. 2013;17(4):179-93. doi: https://doi.org/10.1016/j.tics.2013.02.007

27. Benenzon R. Teoria da musicoterapia. São Paulo: Summus; 1988.

28. Onieva-Zafra MD. The impact of Martha Rogers' nursing science in Spain. J Nurs Care. 2015;4(5):1-3. doi: https://doi.org/10.4172/21671168.1000283

29. Leão ER, Silva MJP. Música e dor crônica músculoesquelética: o potencial evocativo de imagens mentais. Rev Latino Am Enfermagem. 2004;12(2):235-41. doi: https://doi.org/10.1590/S0104-11692004000200013

30. Gonçalez DF, Nogueira AT, Puggina AC. O uso da música na assistência de enfermagem no Brasil: uma revisão bibliográfica. Cogitare Enferm. 2008;13(4):591-6. doi: http://dx.doi.org/10.5380/ce.v13i4.13121 